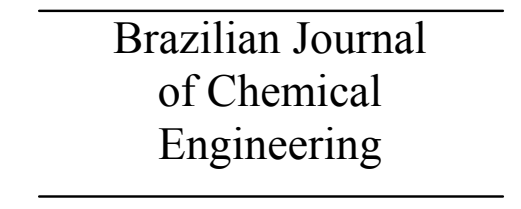

ISSN 0104-6632

Printed in Brazil

www.abeq.org.br/bjche

Vol. 27, No. 04, pp. 601 - 608, October - December, 2010

\title{
SYNTHESIS OF BIODIESEL FROM NEEM OIL USING SULFATED ZIRCONIA VIA TRANESTERIFICATION
}

\author{
H. Muthu ${ }^{1}$, V. SathyaSelvabala ${ }^{1}$, T. K. Varathachary ${ }^{2}$, D. Kirupha Selvaraj ${ }^{1}$, \\ J. Nandagopal ${ }^{2}$ and S. Subramanian ${ }^{*}$ \\ ${ }^{1}$ Department of Chemical Engineering, A. C. College of Technology, Chennai 600 025, India. \\ ${ }^{2}$ Department of Chemistry, Velammal Engineering College, Chennai 600 066, India. \\ *Corresponding author: Sivanesan Subramanian, Phone and Fax: + (91) (44) 22203525 \\ E-mail: sivanesh@yahoo.com
}

(Submitted: April 2, 2010 ; Revised: May 27, 2010 ; Accepted: July 2, 2010)

\begin{abstract}
Sulfated zirconia (SZ) is a widely used catalyst, which is synthesized by a solvent free method and the synthesized catalyst has been characterized. Neem Methyl Ester (Biodiesel) was prepared by a two-step process of esterification and transesterification from Neem oil with methanol in the presence of catalyst. Acid catalyst was used for the esterification and alkali catalyst $(\mathrm{KOH})$ for the transesterification reaction. Optimal Free Fatty Acid (FFA) conversion was achieved using $1 \mathrm{wt} \% \mathrm{SZ}$ as an acid catalyst with a methanol-to-oil molar ratio of 9:1, temperature of $65^{\circ} \mathrm{C}$ and reaction time of $2 \mathrm{~h}$. The acid value was reduced to $94 \%$ of the raw oil $(24.76 \mathrm{mg} \mathrm{KOH} / \mathrm{g})$, which confirmed the conversion. Consequently, this pretreatment reduces the overall complexity of the process and a conversion efficiency of $95 \%$ is achieved when pretreated oil reacts with methanol in the presence of $\mathrm{KOH}$.

Keywords: Neem oil; Heterogeneous catalyst; Sulfated zirconia; Esterification; Biodiesel; Transesterification.
\end{abstract}

\section{INTRODUCTION}

Current trends focus on the search for alternate fuel (biodiesel) for replacing fossil fuels due to the increase in the price and environmental concerns about air pollution (Azam et al., 2005). Biodiesel is defined as the fatty acid methyl ester formed by the transesterification of vegetable oil (edible, nonedible), used cooking oil and animal fats with methanol, either pure or blended with fossil fuel (Lang et al., 2001). The advantages of utilizing biodiesel replacing conventional fuel are that biodiesel is non-toxic, biodegradable, renewable and less pollutant in emissions. Engine life can be prolonged by reducing the frequency of engine part replacement and increasing the lubricity (Angina et al, 2000). Due to the high cost of feed stock used for biodiesel synthesis, it is not yet commercialized globally. Commercial utilization of biodiesel will lead to many advantages like green cover for wasteland, greater support for agriculture and rural economies, thereby reduced dependence on imported crude oil and a smaller rate of increase in air pollution (Angina et al, 2000).

Neem (Azadirochta indica A. Juss) is a native Indian tree well known for its medicinal features. Most of the parts such as leaves, bark, flower, fruit, seed and root have applications in the field of medicine. Neem seed, which has higher concentration of oil ( $30 \%$ oil content) is the major source of Neem oil, which is already in commercial use as an insecticide, lubricant and in medicine to treat various kinds of diseases (Puri, 1999, Ragasa et al., 1997; Barnwal et al., 2005; Johnson et al., 1996).

*To whom correspondence should be addressed 
The annual potential for oil production is 21000 tons. Neem oil contains four significant saturated fatty acids, of which two are palmitic acid and two are stearic acid. It also contains polyunsaturated fatty acids such as oleic acid and linoleic acids.

Conventional manufacturing of biodiesel is by means of the transesterification of oils with methanol in the presence of catalyst, such as alkali $(\mathrm{KOH}$, $\mathrm{NaOH}$ ) (Freedman et al., 1984; Holser et al., 2006). The basic transesterification reactions is as follows:

Oils (triglycerides) + Methanol $\rightarrow$ Biodiesel + Glycerol

Operational parameters vary according to the properties of the feedstock oils and the desired biodiesel quality. Due to the high FFAs content in Neem oil, soap formation may occur due to its affinity towards alkali catalyst used in the transesterification process. For this reason, Neem oil cannot be directly used and so pre-esterification catalyzed by homogenous acids such as sulfuric acid, phosphoric acid or sulfonic acid is carried out to reduce the FFAs so that Neem oil can be successfully transesterified by an alkali catalyst to fatty acid methyl esters (FAME) (Tiwari et al., 2007).

Heterogeneous solid acid catalysts have been used as an alternative to basic and enzyme catalysts, since they can be used in both transesterification and esterification reactions (Kim et al., 2004). However, acid catalysts require high alcohol-to-oil molar ratios and catalyst concentrations to achieve satisfactory transesterification conversions. Industrial processes generally prefer solid catalysts for chemical transformations because of their easy separation from any reaction mixture. In addition, solid catalysts have the potential to be regenerated and are environmentally benign, allowing multiple reuse with little waste released to the environment. Among solid acid catalysts, sulfated zirconia (SZ) has received considerable attention over the last 20 years due to its strong acid properties (Hino et al., 1980; Song et al., 1996; Arata et al., 1988). Several solid acids (zeolites, ion exchange resins, and mixed metal oxides) were investigated as catalysts for the esterification of dodecanoic acid with 2ethylhexanol, 1-propanol and methanol at 130$180^{\circ} \mathrm{C}$ and sulfated zirconia was considered to be the best. Sulfated zirconia showed high activity and selectivity for the esterification of fatty acids with a variety of alcohols (Anton et al., 2006; Antunes et al., 2005).

The aim of the present work is to investigate the performance of sulfated zirconia as a heterogeneous acid catalyst in the esterification of Neem oil. The factors influencing the esterification were systematically investigated. The solid acid catalyst (sulfated zirconia) was prepared by a solvent free method and was tested and characterized. The properties of the biodiesel produced were determined.

\section{EXPERIMENTAL}

\section{Materials}

The oil was purchased from the local market and filtered to remove solid particles. The fatty acid profile and the results of chemical analysis are given in Table 1(a) and 1(b). The chemical composition of Neem oil was analyzed by a gas chromatographic method and the physical-chemical properties by standard procedures (IS 548 (Part 1): 1964 - Methods of sampling and test for oils and fats: Part 1Methods of sampling physical and chemical). Analar grade zirconium oxy chloride, ammonium sulphate, $\mathrm{KOH}$ and methanol were used for catalyst preparation. The methanol used throughout the study was $99 \%$ pure. The acid value was calculated by the following equation

$\mathrm{AV}=\frac{28.2 \mathrm{VN}}{\mathrm{W}}(\mathrm{mgKOH} / \mathrm{g}$ of oil $)$

where $\mathrm{V}$ is the volume of $\mathrm{KOH}, \mathrm{N}$ is the normality of $\mathrm{KOH}$ and $\mathrm{W}$ is the weight of oil.

Table 1(a): Fatty acid profile of Neem oil

\begin{tabular}{|l|l|l|r|r|}
\hline Fatty acid & Systematic Name & Formula & Structure & wt\% \\
\hline Palmitic & Hexadecanoic & $\mathrm{C}_{16} \mathrm{H}_{32} \mathrm{O}_{2}$ & $16: 0$ & 12.01 \\
Stearic & Octadecanoic & $\mathrm{C}_{18} \mathrm{H}_{36} \mathrm{O}_{2}$ & $18: 0$ & 12.95 \\
Oleic & cis-9-Octadecenoic & $\mathrm{C}_{18} \mathrm{H}_{34} \mathrm{O}_{2}$ & $18: 1$ & 34.09 \\
Linoleic & cis-9,cis12-Octadecenoic & $\mathrm{C}_{18} \mathrm{H}_{32} \mathrm{O}_{2}$ & $18: 2$ & 38.26 \\
Lignoceric & Tetracosanoic & $\mathrm{C}_{24} \mathrm{H}_{48} 0_{2}$ & $24: 0$ & 0.3 \\
\hline
\end{tabular}


Table 1(b): Chemical analysis of Neem oil

\begin{tabular}{|c|l|l|}
\hline S. No. & Properties & Characteristics \\
\hline 1. & Color & Greenish yellow \\
2. & Odour & $0.925-0.940$ \\
3. & Specific gravity at $15^{\circ} \mathrm{C}$ & $1.469-1.4772$ \\
4. & Refractive index at $15^{\circ} \mathrm{C}$ & $82-98$ \\
5. & Iodine value & $44 \mathrm{mg} \mathrm{KOH} / \mathrm{g}$ of oil \\
6. & Acid Value & $191-202$ \\
\hline
\end{tabular}

\section{Preparation of the Solid Acid Catalyst by the Solvent-Free Method}

The solvent-free preparation of SZ was accomplished according to the procedure described (Sun et al., 2005). $\mathrm{ZrOCl}_{2} .8 \mathrm{H}_{2} \mathrm{O}$ and $\left(\mathrm{NH}_{4}\right)_{2} \mathrm{SO}_{4}$ in a molar ratio of 1:6 were ground in an agate mortar for $20 \mathrm{~min}$ at room temperature. After standing for $18 \mathrm{~h}$ at room temperature in air, the sample was calcined for $5 \mathrm{~h}$ at $600^{\circ} \mathrm{C}$.

\section{Characterization of the Catalyst}

The acidity of sulfated zirconia was analyzed by the $\mathrm{NH}_{3}$ TPD method. Adsorption of ammonia was carried out on each sample in a quartz tube packed with $100 \mathrm{mg}$ of the sample. The initial flushing was carried out at $450^{\circ} \mathrm{C}$ with pure helium (at $25 \mathrm{cc} / \mathrm{min}$ flow rate) for 1 hour and cooled to $115^{\circ} \mathrm{C}$. Ammonia adsorption was carried out by passing the ammonia vapors over the catalyst bed. Then, helium was passed to remove the physisorbed ammonia. The Xray diffraction (XRD) patterns of the sulfated zirconia were recorded on an X-ray diffractometer (Rigaku D/Max Ultima III) operating under $40 \mathrm{KV}$ and $40 \mathrm{~mA}$ with the scan rate of $2 \% \mathrm{~min}$. $\mathrm{Cu} \mathrm{K}$ X-ray was nickel filtered. The infra red spectrum of the sulfated zirconia was recorded on a Nicolet (AVATAR 360) instrument using the $\mathrm{KBr}$ pellet technique. Shape and size of the sulfated zirconia were examined by Scanning electron microscopy (SEM, Hitachi S-4900).

\section{Two Step Biodiesel Production}

Both the steps of biodiesel production were carried out in a three-necked round bottom flask equipped with a reflux condenser to avoid alcohol evaporation. Stirring was performed with the help of a mechanical stirrer. The temperature of the flask was maintained at different levels using a silicon oil bath, which was connected to a dimmer stat.

\section{Acid Catalyzed Esterification}

Neem oil was poured into the flask and the solid acid catalyst was added, followed by methanol. The progress of the reaction was monitored by measuring the acid value. Reaction parameters were optimized in the temperature range of 30 to $90^{\circ} \mathrm{C}$ with varying catalyst loading $(0.5$ to $1.5 \%)$; the methanol to oil molar ratio was varied from 3 to 12 by keeping the reaction time (2h) constant throughout the reaction. The final reaction mixture was centrifuged at $8000 \mathrm{rpm}$ for $10 \mathrm{~min}$ and the supernatant - that is, the excess methanol, was removed. Solid acid catalyst was separated from the remaining residue, which was further processed by base catalyzed reaction.

\section{Base-Catalyzed Transesterification}

The pretreated oil was poured into the reaction flask and heated. A solution of $\mathrm{KOH}$ in methanol $(1 \%)$ was thermostated at $60^{\circ} \mathrm{C}$ and the pretreated oil was added. The molar ratio of methanol-to-oil was $6: 1$ and the reaction mixture was stirred by a mechanical stirrer. The reaction was stopped after 2 $\mathrm{h}$ and the reaction mixture was poured into a separating funnel. The lower layer containing glycerol and impurities was drawn off. The upper layer of biodiesel was washed three times with hot distilled water. The lower layers were discarded and, after the third washing, the upper layer is the biodiesel product.

\section{Product Analysis}

The acid value of the reaction mixture was determined by the acid base titration technique. The conversion of FFA (reduction in acid value) was calculated using the equation (Gore et al., 1998).

$$
\mathrm{X}_{\mathrm{FFA}}=\frac{\mathrm{a}_{\mathrm{i}}-\mathrm{a}_{\mathrm{t}}}{\mathrm{a}_{\mathrm{i}}}
$$


where $a_{i}$ is the initial acidity and $a_{t}$ is the acidity at time t. Production of biodiesel was confirmed by High Performance Liquid Chromatography (HPLC), equipped with a refractive index detector. A Sphere$5 \mathrm{C}-18$ column at a temperature $40^{\circ} \mathrm{C}$ was used for the separation with a $1 \mathrm{ml} / \mathrm{min}$ flow rate of methanol as the mobile phase. The sample injection volume was $20 \mu \mathrm{L}$ and the components measured by HPLC included triglycerides (TG), diglycerides (DG), monoglycerides (MG) and methyl esters (ME). Calibration curves were used to calculate the weight percentage of the individual components from the integrated peak areas using the respective standards. Physical and chemical properties of fatty acid methyl esters were analyzed by standard procedures.

\section{Washing of Biodiesel}

Biodiesel was washed to remove contaminants like soap, catalyst and other impurities. After separating the unwashed biodiesel and glycerin, water was added to the biodiesel and stirred well. During stirring, a white cloudy substance was formed at the bottom of the tank, which was carefully separated. The washed biodiesel was heated to $100^{\circ} \mathrm{C}$ to remove the remaining water. The washing procedure was repeated four times.

\section{Biodiesel Characterization}

The samples of biodiesel produced were tested for their fuel properties. The flash point was determined in a Pensky-Martens closed-cup tester (ISL, Model FP93 5G2), using ASTM D 93. Cloud point and pour point determinations were made using ASTM D 2500 and ASTM D 97. The kinematic viscosities were determined at $15-40^{\circ} \mathrm{C}$, using a
Viscometer (Anton Parr, Stabinger, Model SVM3000). The procedure of ASTM D 7042 was followed. The water contents were determined following ASTM D 95.

\section{RESULTS AND DISCUSSION}

\section{Characterization of the Catalyst}

The surface and bulk properties of acid catalysts were examined by various spectroscopic and nonspectroscopic techniques, namely X-ray powder diffraction, ammonia-TPD and SEM. A typical XRD pattern (Figure 1) clearly shows the presence of the tetragonal phase of the acid catalyst, given by reflections at $2 \theta=30.18^{\circ}$, as well as peaks at $28.3^{\circ}$, $35.19^{\circ}, 50.770^{\circ}, 59.291^{\circ}, 60.187^{\circ}$ and $63.724^{\circ}$. The patterns resemble those reported in the literature (Deyanira et al., 2006). The Ammonia-TPD results shown in Figure 2 reveal two temperature maxima for both the samples, indicating the presence of two different types of acid sites with different acid strength distributions. The total amount of ammonia desorbed in the case of the salted sample is much higher than that of the pure sample. It clearly indicates that impregnated salt ions have a strong influence on the acidic properties of the raw sample used for catalyst. The Ammonia-TPD characterization result is in agreement with the earlier paper published by Benjaram et al. (2005). Figure 3 shows the SEM photograph of a solid acid catalyst sample calcined at $600^{\circ} \mathrm{C}$, which shows that the average particle size is in the range of 20-30 $\mu \mathrm{m}$ and is in an agglomerated form. Similar photographs have been reported in the literature (Xiaobo Yang et al., 2005).

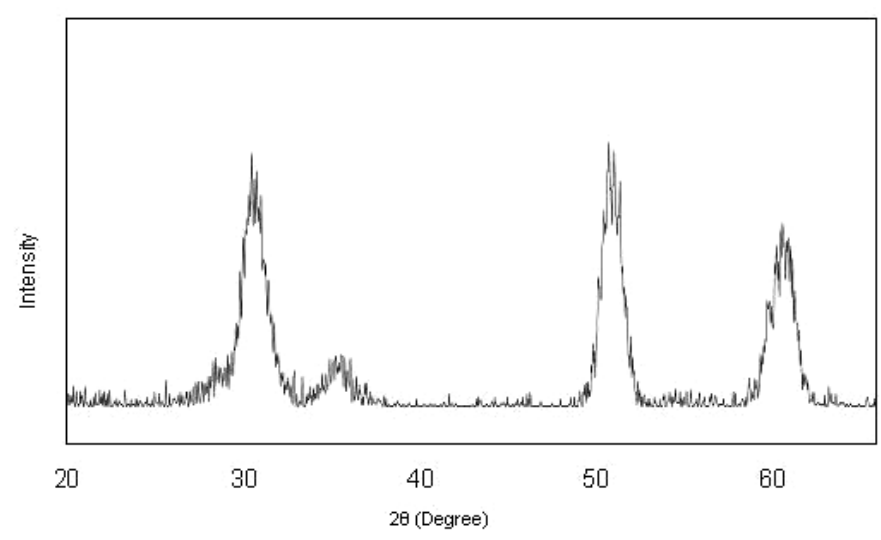

Figure 1: XRD pattern of sulfated zirconia catalyst 


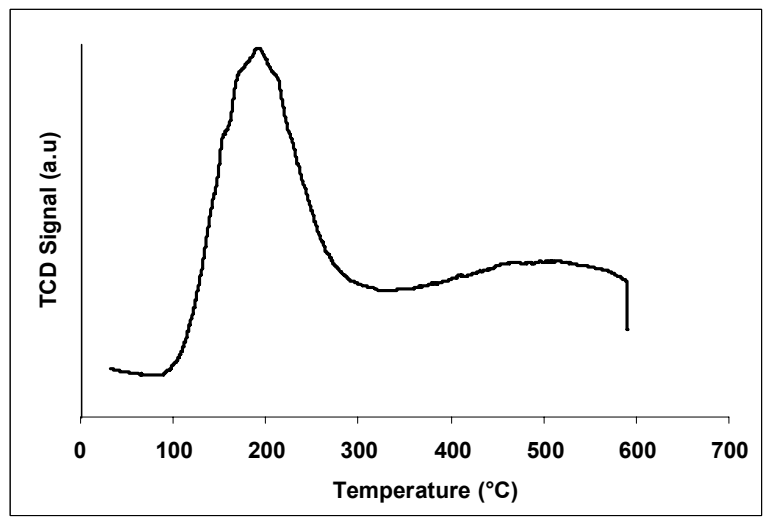

Figure 2: Ammonia TPD profile of sulfated zirconia

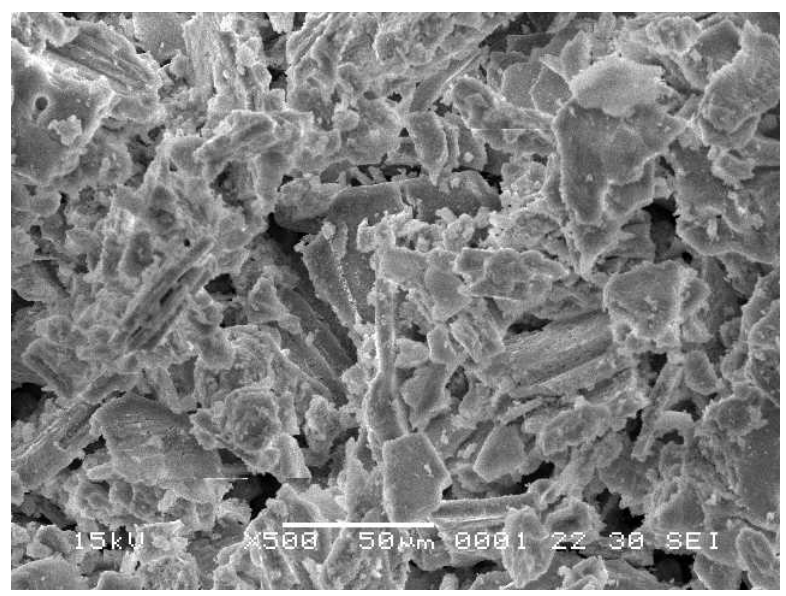

Figure 3: SEM Image of sulfated zirconia

\section{Effect of Process Parameters}

\section{Acid Catalyzed Reaction}

The effect of molar ratio of methanol to oil on esterification was studied at various catalyst amounts and temperatures, as shown in Figure 4(a), (b), (c) and (d). From the results shown, in the case of a molar ratio of methanol to oil of $9: 1$ at $65^{\circ} \mathrm{C}$ with $1 \%$ catalyst amount, the conversion efficiency is $94 \%$. The conversion efficiency for neem oil with SZ is comparable to the result obtained by Sathya Selva Bala et al. (2010) using phosphoric acid-modified mordenite. The catalyst loading required for our experiment was lower when compared to the previous works (Marchetti et al., 2008; Zang et al., 2008). The conversion efficiency of the esterification reaction has less effect when the temperature is raised beyond the boiling point of methanol $\left(70^{\circ} \mathrm{C}\right)$.
The recyclability of the catalyst was studied under the reaction conditions of $65^{\circ} \mathrm{C}, 1 \mathrm{wt} \%$ catalyst, $2 \mathrm{~h}$ and 9:1 methanol/oil molar ratio. The catalyst can be recycled without appreciable loss in activity after calcination of the separated catalyst at $600^{\circ} \mathrm{C}$ for $3 \mathrm{~h}$ in air. We obtained results similar to those of the Anton et al. (2006). A FFA conversion (esterification) of $94 \%$ was obtained in the first run and, thereafter, the conversion decreased with catalyst reuse without calcination, due to catalyst deactivation. The catalyst was not deactivated completely, but a drop in catalytic activity was observed with increasing number of runs. Re-calcination of slightly deactivated catalyst recovers the original activity of the catalyst. According to the experiment carried out by Binghui et al. (1997), the deactivation of sulfated zirconia occurs at $200^{\circ} \mathrm{C}$. Based on results obtained in experiments run in triplicate, the experimental error was less than $3 \%$ in all the cases. 


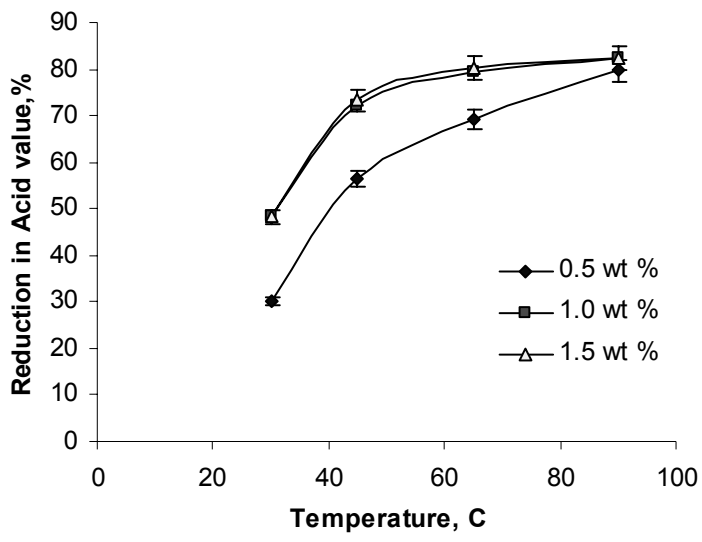

(a)

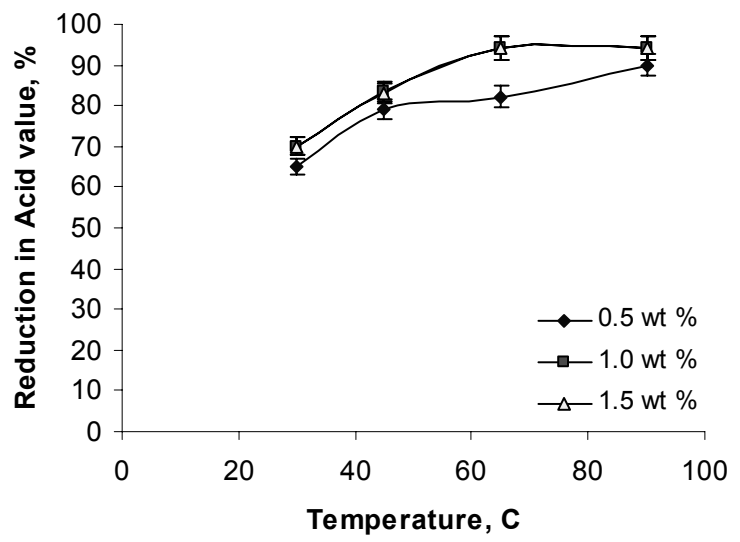

(c)

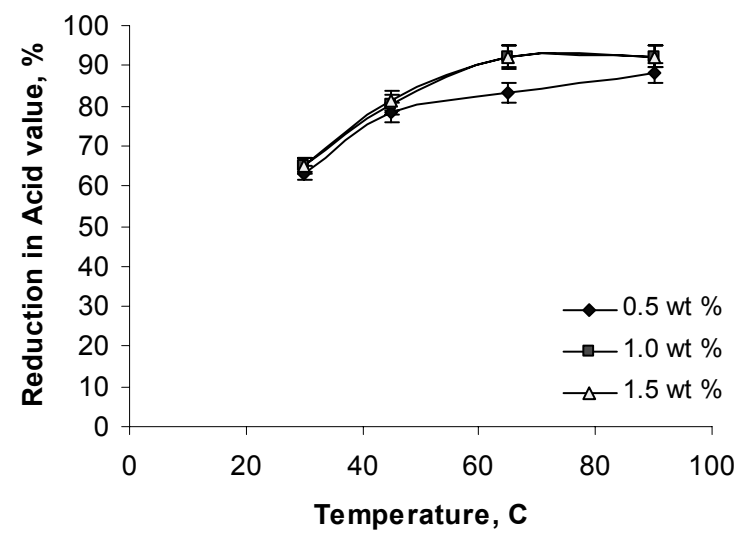

(b)

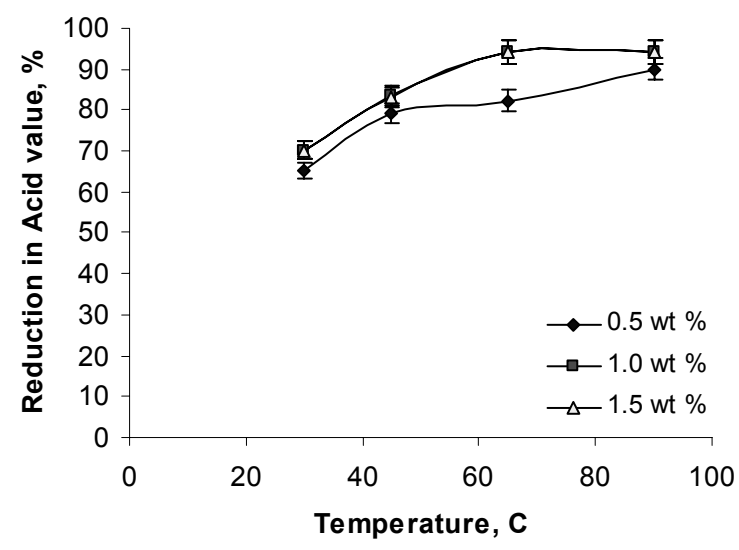

(d)

Figure 4: Effect of temperature and catalyst amount on the reduction of acid value for different methanol to oil molar ratio: (a) 3:1 (b) 6:1 (c) 9:1 (d) 12:1.

\section{Base-Catalyzed Reaction}

Besides the presence of FFA and moisture, as well as the agitation intensity, the base- catalyzed transesterification is also affected by the type and concentration of catalyst, the molar ratio of methanol-to-oil and the reaction temperature. The most often used molar ratio of methanol-to-oil and $\mathrm{KOH}$ amount are $6: 1$ and $1 \%$, respectively (Veljkovic et al., 2006).

A test case of alkaline catalyzed transesterification was run using a pretreated sample that had an acid value well below $2 \mathrm{mg} \mathrm{KOH} / \mathrm{g}$. In this process, a yield of $95 \%$ biodiesel was obtained from Neem oil.

Comparative analysis of conversion efficiencies for heterogeneous acid catalysts, base catalyst and enzyme catalyst with different starting materials from the recently reported literature are given in Table 2 .

\section{Biodiesel Characterization}

The samples of biodiesel produced were tested for their fuel properties. The fuel properties of biodiesel are summarized in Table 3. This table shows that the biodiesel had comparable fuel properties with those of diesel and the values and parameters were within the limits prescribed in the latest ASTM standards for biodiesel. The results obtained were comparable to previous work (Sathyaselvabala et al., 2010). 
Table 2: Comparative analysis of conversion efficiencies for heterogeneous acid catalysts, base catalyst and enzyme catalyst with different starting materials.

\begin{tabular}{|c|c|c|c|c|c|c|c|}
\hline $\begin{array}{c}\text { Initial free fatty } \\
\text { acid amount }\end{array}$ & Catalyst & $\begin{array}{l}\text { Catalyst } \\
\text { loading }\end{array}$ & Time & $\begin{array}{c}\text { Methanol } \\
\text { to oil ratio }\end{array}$ & Temperature & Conversion & Reference \\
\hline $195 \mathrm{mg} \mathrm{KOH} / \mathrm{g}$ & Lipozyme CALB & $2.24 \mathrm{wt} \%$ & 3 days & $16.13: 1$ & $55^{\circ} \mathrm{C}$ & $96 \%$ & Marchetti et al. (2008) \\
\hline $1.25 \mathrm{mg} \mathrm{KOH} / \mathrm{g}$ & Mordenite & $1 \mathrm{~g}$ & $3 \mathrm{hr}$ & $30: 1$ & $60^{\circ} \mathrm{C}$ & $80.9 \%$ & Chung et al. (2008) \\
\hline $24.4 \mathrm{mg} \mathrm{KOH} / \mathrm{g}$ & $\begin{array}{l}\text { Phoshphoric acid } \\
\text { modified mordenite }\end{array}$ & $1 \mathrm{wt} \%$ & $60 \mathrm{~min}$ & $6: 1$ & $60^{\circ} \mathrm{C}$ & $92.5 \%$ & $\begin{array}{l}\text { Sathyaselvabala et al. } \\
\text { (2010) }\end{array}$ \\
\hline $0.5 \mathrm{mg} \mathrm{KOH} / \mathrm{g}$ & Sodium phosphate & $3 \mathrm{wt} \%$ & $20 \mathrm{~min}$ & $9: 1$ & $70^{\circ} \mathrm{C}$ & $94.9 \%$ & Jiang et al. (2010) \\
\hline $9.74 \mathrm{mg} \mathrm{KOH} / \mathrm{g}$ & $\mathrm{KF}$ loaded on $\mathrm{ZnO}$ & $3 \mathrm{wt} \%$ & $9 \mathrm{~h}$ & $10: 1$ & $60^{\circ} \mathrm{C}$ & $87 \%$ & Wenlei Xie et al. (2006) \\
\hline $24.76 \mathrm{mg} \mathrm{KOH} / \mathrm{g}$ & Sulfated zirconia & 1 wt $\%$ & $2 \mathrm{~h}$ & $9: 1$ & $60-65^{\circ} \mathrm{C}$ & $94 \%$ & present work \\
\hline $9.74 \mathrm{mg} \mathrm{KOH} / \mathrm{g}$ & Immobilized lipase & $0.9 \%$ & $6.3 \mathrm{~h}$ & $3.4: 1$ & $36.5^{\circ} \mathrm{C}$ & $92.2 \%$ & Shieh et al. (2003) \\
\hline
\end{tabular}

Table 3: Fuel quality of biodiesel formed by dual step process

\begin{tabular}{|l|c|r|r|}
\hline Properties & Limits & Test methods & Biodiesel quality \\
\hline Flash point, ${ }^{\circ} \mathrm{C}$ & $>130$ & ASTM D93 & 140 \\
Cloud point, ${ }^{\circ} \mathrm{C}$ & & & 13.2 \\
Pour point, ${ }^{\circ} \mathrm{C}$ & & & 4.3 \\
Water and sediments, \% vol. max & 0.050 & ASTM D2709 & 0.005 \\
Kin.viscosity at $40^{\circ} \mathrm{C}(\mathrm{cSt})$ & $1.9-6.0$ & ASTM D445 & 4.00 \\
Cetane number & 47 & ASTM D613 & 57 \\
Distillation temperature & 360 max & ASTM D1160 & 356 \\
\hline
\end{tabular}

\section{CONCLUSION}

In the present investigation, it is found that solid acid catalysts are suitable for oils with a high content of FFA and found to have good stability. Strong acid sites have a significant effect on the catalytic activity of solid acid catalysts in the transesterification of Neem oil with methanol. The high FFA level (24.76 $\mathrm{mg} \mathrm{KOH} / \mathrm{g}$ of oil) of crude Neem oil can be reduced to less than $2 \mathrm{mg} \mathrm{KOH} / \mathrm{g}$ in a solid acid-catalyzed pretreatment process of esterification using sulfated zirconia with a methanol-to-oil ratio of $9: 1$ at $65^{\circ} \mathrm{C}$ during $2 \mathrm{~h}$. The first-step product, which has an acid value of less than 2 , is used for the final alkalicatalyzed $(1 \% \mathrm{KOH})$ transesterification with methanol to produce biodiesel. This process gives a yield of $95 \%$ of biodiesel that has properties comparable to those of petroleum diesel and was within ASTM standards.

\section{NOMENCLATURE}

$\begin{array}{llr}\mathrm{X}_{\mathrm{FFA}} & \begin{array}{l}\text { Conversion of Free Fatty } \\ \end{array} & \text { Acids } \\ \text { FFA } & \text { Free fatty acid } & \mathrm{mg} \mathrm{KOH} / \mathrm{g} \\ \text { AV } & \text { Acid Value } & \text { of oil } \\ & & \mathrm{ml} \\ \mathrm{V} & \text { Volume of } \mathrm{KOH} & \mathrm{N} \\ \mathrm{N} & \text { Normality of } \mathrm{KOH} & \mathrm{g}\end{array}$

\section{REFERENCES}

Angina, S., Ram, P., Triglycerides-based diesel fuels. Renewable and Sustainable Energy Reviews, 4, (2), 111-133 (2000).

Antunes, O. A. C. Interfaces with the industry. Quim. Nova, 28, S64-S75 (2005).

Anton, K. A., Dimian, A. C., Rothenberg, G., Solid acid catalysts for biodiesel production - towards sustainable energy. Adv. Synth. Catal., 348, 7581 (2006).

Arata, K., Hino, M. in: M. J. Philips, M., Ternan (Eds.). Proceedings of the Ninth International Congress Catalysis, Calgary, Canada, Chem. Soc. Can., 1727 (1988).

Azam, M. M., Waris, A., Nahar, N, M., Prospects and potential of fatty acid methyl esters of some non-traditional seed oils for use as biodiesel in India. Biomass and Bioenergy, 29, 293-302 (2005).

Barnwal, B. K., Sharma, M. P., Prospects of biodiesel production from vegetable oils India. Renewable and Sustainable Energy Reviews, 9, 363-378 (2005).

Benjaram, M., Reddy., Pavani, M., Sreekanth, Pandian Lakshmanan, Sulfated zirconia as an efficient catalyst for organic synthesis and transformation reactions. Journal of Molecular Catalysis, A: Chemical 237, 93-100 (2005).

Binghui, Lia and Richard, D., Gonzalez, TGA/FT-IR studies of the deactivation of sulfated zirconia 
catalysts. Applied Catalysis A: General, Volume 165, Issues 1-2, 31, 291-300 (1997).

Chung, K. H., Chang, D. R., Park, B. G., Removal of free fatty acid in waste frying oil by esterification with methanol on zeolite catalysts. Bioresource Technology, 99, 7438-7443 (2008).

Deyanira, A. B, Leticia, L. R, Victor, H. L.C., Eduardo, G. Z. and Guillermo, N. S., Sulfated ZirconiaCatalyzed Synthesis of 3,4-Dihydropyrimidin2(1H)-ones (DHPMs) Under Solventless Conditions: Competitive Multicomponent Biginelli vs. Hantzsch Reactions. Molecules, 11, 731-738 (2006).

Freedman, B., Pryde, E. H., and Mounts, T. L., Variables affecting the yields of fatty esters from transesterified vegetable oils. Journal of the American Oil Chemists' Society, 61, 1638-1643 (1984).

Gore, R. B., Thomson, W. J., Pulsed gas-phase alkylation of isobutane/2-butene over sulfated zirconia. Appl. Catal., A, 168, 23-32 (1998).

Hino, M., Arata, K., Synthesis of solid superacid catalyst with acid strength. J. Chem. Soc. Chem. Commun., 16.04: 851 (1980).

Holser, R. A. and Harry-O'Kuru, R., Transesterified milkweed (Asclepias) seed oil as a biodiesel fuel. Fuel, 85, 2106-2110 (2006).

IS 548 (Part 1): Methods of sampling and test for oils and fats: Part 1- Methods of sampling physical and chemical (1964).

Jiang, S. T., Zhang, F. J. and Pan, L. J., Sodium phosphate as a solid catalyst for biodiesel preparation. Braz. J. Chem. Eng., 27, (1), 137-144 (2010).

Johnson, S., Morgan, E. D. and Peiris, C. N., Development of the Major Triterpenoids and Oil in the Fruit and Seeds of Neem (Azadirachta indica). Journal of Annals Botany, 78: 383-388 (1996).

Kim, H. J., Kang, B. S., Kim, M. J., Park, Y. M., Kim, D. K., Lee, J. S., Lee, K. Y., Transesterification of vegetable oil to bio-diesel using heterogeneous base catalyst. Catal. Today, 93-95: 315-320 (2004).

Lang, X., Dalai, A. K., Bakhshi, N. N., Reaney, M. J., Hertz, P. B., Preparation and characterization of bio-diesel from various bio-oils. Bioresource Technol., 80, 53-62 (2001).

Marchetti, J. M., Miguel, V. U., Errazu, A. F., Heterogeneous esterification of oil with high amount of free fatty acids. Fuel, 86, 906-910 (2007).

Narasimharao, K., Brown, D. R., Lee, A. F., Newman, A. D., Siril, P. F., Tavener, S. J. and
Wilson, K., Structure-activity relations in Csdoped heteropolyacid catalysts for biodiesel production. Journal of Catalysis, 248, 226-234 (2007).

Ni, J., Meunier, F. C., Esterification of free fatty acids in sunflower oil over solid acid catalysts using batch and fixed bed-reactors. Appl. Cat., A. 333, (1). 122-130 (2007).

Puri, H. S., Neem-The Divine Tree. Harwood Academic Publishers, Amsterdam (1999).

Ragasa, C. Y., Nacpil, Z. D., Natividad, G. M., Tada, M., Coll, J. C. and Rideout, J. A., Tetranortriterpenoids from Azadirachta Indica. Journal of Phytochemistry. 46, 555-558 (1997).

Sathyaselvabala, V., Thiruvengadaravi, K. V., Dinesh Kirupha, S., Vijayalakshmi, P. and Sivanesan, S., Removal of free fatty acid in Azadirachta indica (Neem) seed oil using phosphoric acid modified mordenite for biodiesel production. Bioresour. Technol., 101, (15), 5897-5902 (2010).

Song, X. M., Sayari, A., Characterization of Platinum on Sulfated Zirconia Catalysts by Temperature Programmed Reduction. Catal. Rev. Sci. Eng., 38, 329 (1996).

Shieh, C. J., Liao, H. F. and Lee, C. C., Optimization of lipase-catalyzed biodiesel by response surface methodology. Bioresource Technology, 88, (2), 103-106 (2003).

Sun, Y., Ma, S., Du, Y., Yuan, L., Wang, S., Yang, J., Deng, F., Xiao, F.- S,. Solvent-free preparation of nanosized sulfated zirconia with Brønsted acidic sites from a simple calcination. J. Phys. Chem., B 109, 2567-2572 (2005).

Tiwari, A. K., Kumar, A. and Raheman, H., Biodiesel production from jatropha oil (Jatropha curcas) with high free fatty acids: An optimized process. Biomass Bioenergy, 31, 569-575 (2007).

Veljkovic, V. B., Lakicevic, S. H., Stamenkovic, O. S., Todorovic, Z. B., Lazic, M. L., Biodiesel production from tobacco (Nicotiana tabacum L.) seed oil with a high content of free fatty acids. Fuel, 85, 2671-2675 (2006).

Yang, X., Jentoft, R. E. and Jentoft, F. C., n-Butane Isomerization Catalyzed by Sulfated Zirconia Nanocrystals Supported on Silica or $\gamma$-Alumina. Catalysis letters, 105, 195-203 (2005).

Wenlei, X. and Xiaoming, H., Synthesis of Biodiesel from Soybean Oil using Heterogeneous KF/ZnO Catalyst. Catalysis Letters, Volume 107, Numbers 1-2, 53-59 (2006)

Zhang, J., Jiang, L. Acid catalyzed esterification of Zanthoxylum bungeanum oil with high free fatty acids for biodiesel production. Bioresour. Technol., 99, (18), 8995-8998 (2008). 